\title{
Anna Grzywacz
}

Uniwersytet Jagielloński

DOI: $10.19195 / 1733-5779.21 .9$

\section{Dopuszczalność i charakter prawny instytucji prokury łącznej niewłaściwej w świetle nowelizacji Kodeksu cywilnego z dnia 16 grudnia 2016 r.}

\section{JEL Classification: K15}

Słowa kluczowe: reprezentacja, prokura, prokura łączna niewłaściwa, nowelizacja Kodeksu cywilnego

Keywords: representation, procuration, incorrect joint commercial representation, amendment of the civil code

Abstrakt: W artykule opisano instytucję prokury oraz zmiany w sposobie reprezentacji spółki, jakie wprowadza nowelizacja Kodeksu cywilnego z dnia 16 grudnia 2016 r. W świetle najnowszej regulacji dopuszczalna stała się konstrukcja prokury łącznej niewłaściwej. Autorka prezentuje kluczowe orzeczenia Sądu Najwyższego w tym przedmiocie oraz poddaje analizie konsekwencje omawianej zmiany. Określenie sposobu reprezentacji spółki ma fundamentalne znaczenie dla przedsiębiorców, dlatego od wielu lat budziło ono kontrowersje i do czasu wspomnianej nowelizacji brakowało jednoznacznego stanowiska doktryny w tym temacie.

\section{Admissibility and the legal nature of inappropriate joint procuration in the light of the amendment of the Civil Code of 16 December 2016}

\footnotetext{
Abstract: This article describes the institution of the power of attorney in a company and the changes in the way of representation of the company introduced by the amendment of the Civil Code of 16 December 2016. In the light of the latest regulations, the construction of the inappropriate joint procuration has become admissible. The author presents the most important rulings of the Supreme Court and analyzes the consequences of this change. Determining how a company should be represented is fundamental to businessman and has arisen lots of controversies in the past years.
} 


\section{Uwagi wprowadzające}

Problematyka reprezentacji w spółkach kapitałowych budzi wiele kontrowersji. W dzisiejszych czasach, w dobie globalizacji i swobody działalności gospodarczej, przedsiębiorstwa coraz częściej działają nie tylko na rynkach krajowych, lecz także międzynarodowych, poszerzając zakres swojej działalności o nowe obszary. Konsekwentnie zarządy spółek kapitałowych nie są w stanie fizycznie i właściwie wykonywać funkcji reprezentanta spółki ${ }^{1}$. Na znaczeniu zyskuje instytucja dokonywania czynności prawnych przez przedstawiciela. Kodeks cywilny wskazuje dwa rodzaje przedstawicielstwa, tzn. umocowanie mające oparcie w ustawie (przedstawicielstwo ustawowe) albo powstające w wyniku oświadczenia reprezentowanego (pełnomocnictwo) $)^{2}$.

Prokura stanowi postać pełnomocnictwa handlowego. Kodeks spółek handlo$w_{y c h}^{3}$ nie zawiera w zasadzie regulacji instytucji prokury. Odwołuje się w tej kwestii do przepisów Kodeksu cywilnego ${ }^{4}$. Zgodnie z art. $109^{1} \S 1$ k.c. prokurę definiuje się jako pełnomocnictwo udzielone przez przedsiębiorcę, podlegające obowiązkowi wpisu do rejestru przedsiębiorców, które obejmuje umocowanie do czynności sądowych i pozasądowych, jakie są związane z prowadzeniem przedsiębiorstwa. Prokurent ma za zadanie reprezentować spółkę, przez co „należy rozumieć dokonywanie czynności prawnych w stosunkach zewnętrznych"”.

W prawie polskim reprezentacja spółki kapitałowej stanowi (z drobnymi wyjątkami ${ }^{6}$ ) wyłączną kompetencję zarządu. Zarząd spółki jako organ menadżerski jest uprawniony do zawierania umów w imieniu reprezentowanej spółki, występowania przed sądami, składania oświadczeń woli oraz do innych czynności sądowych i pozasądowych. Ma również za zadanie działać w interesie spółki i wspólników bądź akcjonariuszy ${ }^{7}$. Reprezentacja spółki przez zarząd dotyczy sfery zewnętrznych stosunków spółki, tj. stosunków między spółką a osobami trzecimi ${ }^{8}$. Prokurent ma węższy zakres prawa do reprezentacji niż zarząd spółki, co wynika z art. 204 § 1 k.s.h., a sposób reprezentacji spółki różni się w zależności od jej rodzaju. Problematyka reprezentacji spółek kapitałowych jest uregulowana w dwóch analogicznych przepisach k.s.h. - art. 204 dla spółki z ograniczoną odpowiedzialnością oraz art. 372 dla spółki akcyjnej. Ustawodawca dopuszcza

1 W. Pyzioł, A. Szumański, I. Weiss, Prawo spótek, Warszawa 2014, s. 500.

2 Art. 96 Ustawy z dnia 23 kwietnia 1964 r. — Kodeks cywilny (Dz.U. z 1964 r. Nr 16, poz. 93; dalej: k.c.).

${ }^{3}$ Ustawa z dnia 15 września 2000 r. — Kodeks spółek handlowych (Dz.U. z 2000 r. Nr 94, poz. 1037 ze zm.; dalej: k.s.h.).

4 Dz.U. z 1964 r. Nr 16, poz. 93.

5 W. Pyzioł, A. Szumański, I. Weiss, op. cit., s. 487.

6 Zob. ibidem, s. 500.

7 W zależności od rodzaju spółki (sp. z o.o. lub sp. akcyjna).

${ }^{8}$ M. Borkowski, Wykonywanie przez zarząd kompetencji do reprezentacji spótki z o.o., [w:] idem, Reprezentacja spółki z ograniczona odpowiedzialnościa, Warszawa 2009. 
jednak możliwość wprowadzenia modyfikacji poprzez zmianę statutu (umowy) spółki. Zgodnie z art. $205 \S 1$ oraz z art. $373 \S 1$ k.s.h., jeżeli statut nie zawiera żadnych postanowień w tym przedmiocie, do składania oświadczeń w imieniu spółki wymagane jest współdziałanie dwóch członków zarządu (tzw. reprezentacja łączna) albo jednego członka zarządu wraz z prokurentem (tzw. reprezentacja mieszana).

Właściwa forma reprezentacji spółki ma kluczowe znaczenie, gdyż m.in. od niej zależy ważność i skuteczność dokonanych przez reprezentanta czynności prawnych w imieniu spółki. Aby możliwa była ocena poprawności wybranej formy, należy w pierwszej kolejności rozróżnić reprezentację spółki dokonywaną przez organ i przez pełnomocnika. Przedmiotem niniejszego artykułu jest instytucja prokury, dlatego dalsze rozważania będą dotyczyły tej konstrukcji prawnej.

\section{Prokura jako szczególny rodzaj pełnomocnictwa}

Prokura jest pełnomocnictwem szczególnego rodzaju o ustawowo określonym zakresie umocowania. $\mathrm{Z}$ tego względu w sprawach nieuregulowanych stosuje się przepisy o pełnomocnictwie. Szczególne regulacje dotyczące prokury to w obecnym brzmieniu Kodeksu cywilnego 9 przepisy art. $109^{1}-109^{8}$. Nowelizacja Kodeksu cywilnego z 2003 r. sprawiła, że instytucja ta stała się dostępna dla wszystkich wpisanych do rejestru przedsiębiorców ${ }^{10}$. Przez przedsiębiorcę rozumie się, w myśl regulacji Kodeksu cywilnego, osobę fizyczną, osobę prawną i jednostkę organizacyjną, której ustawa przyznaje zdolność prawną, prowadząca we własnym imieniu działalność gospodarczą lub zawodową ${ }^{11}$.

\section{Ustanowienie, odwołanie i wygaśniecie prokury}

Prokura jest pełnomocnictwem, które zasadniczo charakteryzują dwie cechy: szczególna kwalifikacja podmiotów uprawnionych do jej udzielenia (ograniczony zakres podmiotowy) oraz ściśle określony zakres przedmiotowy ${ }^{12}$. Umocowanie odnosi się do czynności sądowych i pozasądowych związanych z prowadzeniem przedsiębiorstwa. Należy przy tym wspomnieć, że prawa reprezentacji prokurenta nie można ograniczyć ze skutkiem prawnym wobec osób trzecich, chyba że przepis szczególny stanowi inaczej ${ }^{13}$. Jak już zostało wspomniane, prokury może udzielić jedynie przedsiębiorca. Warto zauważyć, że w chwili udzielania prokury

9 Po nowelizacji, która weszła w życie 1 stycznia 2017 r.

10 Zob. Ustawa z dnia 14 lutego 2003 r. o zmianie ustawy — Kodeks cywilny oraz niektórych innych ustaw (Dz.U. z 2003 r. Nr 49, poz. 408).

11 Art. $43^{1}$ k.c.

12 M. Wyrwiński, Komentarz do niektórych przepisów kodeksu cywilnego (dotyczących firmy i prokury), zmienionych ustawa z dnia 14 lutego 2003 r. o zmianie ustawy - Kodeks cywilny oraz niektórych innych ustaw, Dz.U.03.49.408, LEX/el. 2003.

13 Art. $109^{1} \S 2$ k.c. 
nie musi on widnieć w rejestrze przedsiębiorców. Profesor Maksymilian Pazdan podkreśla, że uprawnionym jest ten, kto podlega obowiązkowi rejestracji, a nie przedsiębiorca wpisany do rejestru ${ }^{14}$.

W doktrynie przyjmuje się, że udzielenie prokury jest czynnością jednostron$n^{15}{ }^{15}$. Do jej ustanowienia wymagana jest ad solemnitatem forma pisemna, co expressis verbis wynika $\mathrm{z}$ art. $109^{2} \mathrm{k} . c$. W odniesieniu do spółki z ograniczoną odpowiedzialnością i spółki akcyjnej niezbędna jest zgoda wszystkich członków zarządu (art. $208 \S 6$ oraz art. $371 \S 4$ k.s.h.). W praktyce udzielenie takiej zgody następuje w drodze (jednomyślnej) uchwały zarządu ${ }^{16}$. Podmiot, któremu udzielana jest prokura, musi być osobą fizyczną posiadającą pełną zdolność do czynności prawnych. Obecnie dopuszcza się również na zasadzie lex specialis możliwość udzielenia prokury osobie prawnej ${ }^{17}$. W sytuacji niespełnienia powyższych kryteriów ustanowienie prokurenta będzie z mocy prawa nieważne, a wpisanie takiej osoby do rejestru jako prokurenta nie będzie miało znaczenia.

Wykreślenie przedsiębiorcy z rejestru, ogłoszenie upadłości, otwarcie likwidacji, przekształcenie przedsiębiorcy bądź śmierć prokurenta to ustawowe przesłanki powodujące wygaśnięcie prokury ${ }^{18}$. Śmierć przedsiębiorcy lub utrata przez niego zdolności do czynności prawnych nie powoduje wygaśnięcia prokury. Odwołanie prokury jest możliwe w każdym czasie oraz, analogicznie do ustanowienia, jest czynnością jednostronną. Nie ma natomiast wymogu co do formy tej czynności prawnej. Dyskusyjne jest określenie podmiotu, do którego takie oświadczenie winno być adresowane ${ }^{19}$. Nie ulega jednak wątpliwości, że prokurent powinien być poinformowany o zaistniałym zdarzeniu. Ma to na celu niedoprowadzenie do sytuacji, w której nieświadomy braku umocowania nadal będzie wykonywał swoje obowiązki.

Regulacja kodeksowa nakłada na przedsiębiorcę obowiązek zgłoszenia do rejestru zarówno faktu ustanowienia, jak i wygaśnięcia prokury ${ }^{20}$. Konstrukcja akcentująca jawność rejestru ma gwarantować pewność obrotu i tym samym umożliwiać osobom trzecim powołanie się na domniemanie prawdziwości danych wpisanych w rejestrach sądowych. Prokurentom daje natomiast możliwość skutecznego wylegitymowania się w postępowaniach dowodowych.

14 M. Pazdan, [w:] Kodeks cywilny. Komentarz. Suplement, red. K. Pietrzykowski, Warszawa 2003, s. 79.

15 Tak m.in. J. Szwaja, [w:] S. Sołtysiński, A. Szajkowski, J. Szwaja, Kodeks handlowy. Komentarz, t. 1, Warszawa 1997, s. 495; M. Pazdan, op. cit., s. 73.

$16 \mathrm{http}$ ///ksiegowosc.infor.pl/obrot-gospodarczy/spolki/734421,Prokura-udzielenie-wykonywanie-wypowiedzenie.html (dostęp: 17.07.2017).

17 Zob. M. Pazdan, op. cit., s. 82.

18 Art. $109^{7}$ k.c.

19 M. Wyrwiński, Komentarz do zmiany art. 109 (7) Kodeksu cywilnego wprowadzonej przez Dz.U. z 2003 r. Nr 49 poz. 408, LEX/el. 2003.

${ }^{20}$ Art. $109^{8} \S 1$ k.c. 


\section{Rodzaje prokury}

Na gruncie obowiązującego Kodeksu cywilnego, po zmianach wprowadzonych nowelizacją z dnia 16 grudnia 2016 r., wyróżnić można cztery dopuszczalne przez polskie prawo rodzaje prokury: prokurę oddziałową, łączną, łączną niewłaściwą oraz samodzielną (samoistną).

Prokura samoistna, jak sama nazwa wskazuje, jest konstrukcją pozwalającą prokurentowi na samodzielne działanie związane $\mathrm{z}$ prowadzeniem przedsiębiorstwa spółki. Zgodnie z artykułem $109^{5}$ k.s.h. prokurę można ograniczyć do zakresu spraw wpisanych do rejestru oddziału przedsiębiorstwa. Będzie to tzw. prokura oddziałowa, ograniczona przez mocodawcę do reprezentacji w zakresie spraw dotyczących oddziału, a nie całego przedsiębiorstwa.

W wypadku prokury łącznej do dokonania określonej czynności konieczne jest współdziałanie przynajmniej dwóch osób. Ustawodawca nie precyzuje jednak sposobu wykonywania takiej prokury. Ważny jest aspekt współdziałania oraz minimalna liczba prokurentów zobowiązanych do łącznego działania, niekoniecznie ich „konfiguracja”21.

Prokura łączna niewłaściwa polega z kolei na umocowaniu prokurenta do działania wspólnie z członkiem organu zarządzającego lub wspólnikiem uprawnionym do reprezentowania handlowej spółki osobowej. Jest to nowa konstrukcja prawna, wprowadzana do Kodeksu cywilnego nowelizacją z dnia 16 grudnia 2016 r. poprzez dodanie $\mathrm{w}$ art. $109^{4}$ paragrafu $\S 1^{1} \mathrm{w}$ brzmieniu:

Prokura może obejmować umocowanie także albo wyłącznie do dokonywania czynności wspólnie z członkiem organu zarządzającego lub wspólnikiem uprawnionym do reprezentowania handlowej spółki osobowej ${ }^{22}$.

Warto nadmienić, że czym innym jest reprezentacja mieszana w spółce. Te na pozór podobne konstrukcje różnią się i należy je rozgraniczyć. Mieszana reprezentacja spółki opiera się na działaniu członka zarządu ograniczonego w sposobie wykonywania reprezentacji przez prokurenta ${ }^{23}$. W wypadku prokury łącznej niewłaściwej ograniczenie dotyczy natomiast prokurenta, który jest upoważniony tylko do działania z członkiem organu zarządzającego lub wspólnikiem osobowej spółki handlowej (umocowanym do reprezentacji). Występuje on jako osoba odrębna od spółki, działająca w cudzym imieniu. Status członka zarządu jest więc odmienny niż status przedstawiciela ${ }^{24}$.

21 Zob. M. Wyrwiński, Komentarz do zmiany art. 109 (4)...

22 Ustawa z dnia 16 grudnia 2016 r. o zmianie niektórych ustaw w celu poprawy otoczenia prawnego przedsiębiorców (Dz.U. z 2016 r. poz. 2255).

${ }^{23}$ Zob. odpowiednio dla spółki z o.o. — art. 205 k.s.h., spółki akcyjnej — art. 373 k.s.h.

24 Z. Radwański, Prawo cywilne - część ogólna, Warszawa 2015, s. 186-187. 
W dalszej kolejności omówione zostaną kluczowe orzeczenia Sądu Najwyższego sprzed rzeczonej nowelizacji oraz aktualny stan prawny w zakresie prokury łącznej niewłaściwej.

\section{Prokura łączna niewłaściwa w świetle orzecznictwa Sądu Najwyższego}

Sąd Najwyższy niejednokrotnie rozstrzygał kwestię dopuszczalności w polskim prawie konstrukcji prokury łącznej niewłaściwej. W orzecznictwie SN widać jednak pewną niekonsekwencję, gdyż w niektórych przypadkach wyrażał on swoją aprobatę, a niekiedy krytycznie wypowiadał się w przedmiocie tej konstrukcji prawnej. Przykładowo w orzeczeniu z dnia 18 lutego $1938 \mathrm{r}^{25}$ oraz w uchwale z 27 kwietnia 2001 r. ${ }^{26} \mathrm{SN}$ dopuścił możliwość ustanowienia prokury łącznej niewłaściwej. Podstawą miały być stosowane przez analogię przepisy o prokurze ${ }^{27}$. Zgodnie ze stanowiskiem SN wyrażonym we wspomnianej uchwale dopuszczalne jest udzielenie prokury jednej osobie z zastrzeżeniem, że może ona działać tylko łącznie z członkiem zarządu spółki lub wspólnikiem. Warto nadmienić, że zastrzeżenie takie było skuteczne wobec osób trzecich. W ocenie Sądu prokura udzielona określonej osobie w powyższy sposób nie mieści się w pojęciu prokury łącznej wynikającym z art. 62 k.h. (obecnie art. $109^{4} \S 1$ k.c.), albowiem w takiej sytuacji prokurentem jest tylko ta jedna osoba. Członek zarządu lub wspólnik nie mogą być uznani za prokurentów, co byłoby dopuszczalne przy prokurze łącznej ${ }^{28}$. $\mathrm{Z}$ przywołanego orzeczenia wynika, że ustawa ${ }^{29}$, przewidując przy prokurze łącznej działanie prokurenta tylko przy współudziale drugiej osoby, bynajmniej nie zabraniała, aby tą drugą osobą był członek zarządu spółki akcyjnej.

Kilkanaście lat później, jeszcze przed zmianą przepisów, Sąd Najwyższy ponownie pochylił się nad kwestią dopuszczalności prokury łącznej niewłaściwej i w uchwale $\mathrm{z}$ dnia 30 stycznia $2015 \mathrm{r} .{ }^{30}$ zaprezentowal odmienne stanowisko, odrzucając możliwość ustanowienia tego rodzaju pełnomocnictwa.

\section{Uchwała Sądu Najwyższego w składzie siedmiu sędziów z dnia 30 stycznia 2015 r. III CZP 34/14}

Sąd Najwyższy w uchwale III CZP 34/14 przyjął stanowisko, że prokura łączna niewłaściwa jest niedopuszczalna $\mathrm{w}$ świetle prawa polskiego. Zaprzeczył tym sa-

25 Uchwała SN z dnia 18 lutego 1938 r., CI 170/37, OSNC 1938/12/561.

26 Uchwała SN z dnia 27 kwietnia 2001 r., III CZP 6/01, OSNC 2001/10/148.

27 „Wobec braku w tym zakresie specjalnych przepisów, należy stosować w drodze analogii także w odniesieniu do reprezentacji mieszanej spółek osobowych” (ibidem).

28 Zob. uchwała SN z dnia 23 sierpnia 2006 r., III CZP 68/06, OSNC 2007/6/82.

29 Rozporządzenie Prezydenta Rzeczypospolitej z dnia 27 czerwca 1934 r. - Kodeks handlowy (Dz.U. z 1934 r. Nr 57, poz. 502). Obecnie regulacje te znajdują się w k.s.h.

30 Uchwała SN z dnia 30 stycznia 2015 r., III CZP 34/14, OSNC 2015/7-8/80. 
mym wcześniej podjętym przez siebie uchwałom i wydanym orzeczeniom ${ }^{31}$. Sąd Najwyższy w składzie siedmiu sędziów miał za zadanie rozstrzygnąć problem prawny przedstawiony przez Pierwszego Prezesa Sądu Najwyższego we wniosku z dnia 11 kwietnia 2014 r. ${ }^{32}$ : „Czy możliwy jest wpis do Krajowego Rejestru Sądowego, w rubryce »Prokurenci«, jednego prokurenta z jednoczesnym zastrzeżeniem, że może on działać tylko łącznie z członkiem zarządu spółki?". Odpowiadając na zadane pytanie, Sąd Najwyższym stwierdził, że nie jest dopuszczalny wpis do rejestru przedsiębiorców w Krajowym Rejestrze Sądowym jednego prokurenta z zastrzeżeniem, że może on działać tylko łącznie z członkiem zarządu. Tym samym odrzucił możliwość stosowania konstrukcji prokury łącznie niewłaściwej przez przedsiębiorców.

Argumentując przyjęte przez siebie stanowisko, SN powołał się bezpośrednio na regulacje Kodeksu cywilnego i wskazał na brak przepisu, który expressis verbis zezwalałby na ustanowienie prokury polegającej na tym, że ustanawia się jednego prokurenta, ale wskazuje, iż jest to prokura łączna wykonywana z członkiem zarządu. Tym samym skoro ustawodawca nie zawarł takiej konstrukcji prawnej w nowelizacji z 2003 r. ${ }^{33}$, wprowadzając do Kodeksu cywilnego instytucję prokury, należy wnioskować, że nie jest to forma dopuszczalna. W opinii Sądu, stosując wykładnię językową, można wyróżnić jedynie trzy rodzaje prokury: samoistną, łączną oraz oddziałową.

Za odrzuceniem konstrukcji prokury łącznej niewłaściwej przemawiają również, według Sądu Najwyższego, określone w art. 38 k.c. zasady kształtowania reprezentacji osoby prawnej. Przepis ten mówi, że osoba prawna działa przez swoje organy w sposób przewidziany w ustawie lub statucie. Za niedopuszczalną należy więc uznać modyfikację zasad reprezentacji spółki przez oświadczenie woli członka zarządu, co ma miejsce w przypadku prokury łącznej niewłaściwej. Sąd Najwyższy stwierdził następnie, że uznanie za dopuszczalne ustanowienia prokury niewłaściwej uzależniałoby skuteczność oświadczenia woli prokurenta składanego w imieniu spółki od złożenia oświadczenia woli także przez członka zarządu. Prokurent nie może być, zgodnie z prawem, podporządkowany organom menadżerskim spółki. Sąd Najwyższy odrzuca również możliwość analogicznego stosowania art. 205 i 373 k.s.h. w rzeczonej kwestii. Niewątpliwie czym innym, w świetle poczynionych wyżej uwag, jest konstrukcja prawna reprezentacji mieszanej. Rozróżnienie tych dwóch pojęć zostało już szczegółowo omówione.

Brak podstawy prawnej wynika ponadto z faktu, iż ustanowienie prokury jest czynnością jednostronną i tym samym istnieje numerus clausus dopuszczalnych przez prawo czynności jednostronnych. Co za tym idzie — nie ma możliwości do-

31 Zob. uchwała SN z dnia 18 lutego 1938 r. i uchwała SN z dnia 27 kwietnia 2001 r.

32 Wniosek Pierwszego Prezesa Sądu Najwyższego z dnia 11 kwietnia 2014 r., BSA I-4110$5 / 14$.

33 Dz.U. z 2003 r. Nr 49, poz. 408. 
konania każdego rodzaju czynności, byleby nie wykraczały poza granice określone w art. 58 k.c., lecz można dokonywać tylko takich, które określa ustawodawca. Skoro Kodeks cywilny expressis verbis nie zawiera regulacji prokury łącznej niewłaściwej, należy rozumieć, że nie jest ona dopuszczalna jako sprzeczna z ustawą albo mająca na celu obejście ustawy.

Nie bez znaczenia są też przepisy stanowiące o Krajowym Rejestrze Sądowym i rejestrze przedsiębiorców. Wynika z nich, że system wpisów do tego rejestru nie przewiduje możliwości wpisywania prokury niewłaściwej. Rubryka przeznaczona prokurze wymaga uzupełnienia imienia, nazwiska i numeru PESEL prokurenta oraz uściślenia rodzaju prokury. Członek zarządu nie jest prokurentem, stąd problem, w której rubryce należałoby umieścić wzmiankę, że prokurent może skutecznie składać oświadczenia woli tylko łącznie z członkiem zarządu. Wpis taki zostałby uznany za niewłaściwy i konsekwentnie zostałby wykreślony na mocy art. 12 ust. 3 ustawy o Krajowym Rejestrze Sądowym ${ }^{34}$.

\section{Konsekwencje wprowadzenia prokury łącznej niewłaściwej do Kodeksu cywilnego nowelizacją z dnia 16 grudnia $2016 \mathrm{r}$.}

Ustawodawca, dostrzegając potrzeby praktyki, zdecydował się nowelizacją z dnia 16 grudnia 2016 r. wprowadzić do Kodeksu cywilnego artykuł $109^{4} \S 1^{1}$, który expressis verbis dopuszcza możliwość ustanowienia prokurenta umocowanego do dokonywania czynności wspólnie z członkiem organu zarządzającego lub wspólnikiem uprawnionym do reprezentowania handlowej spółki osobowej. Oznacza to, że z dniem 1 stycznia 2017 r. przedsiębiorcy uzyskali możliwość legalnego umocowania prokurenta łącznego niewłaściwego do reprezentacji spółki.

Najważniejszą przesłanką wprowadzenia prokury łącznej niewłaściwej do kodeksu jest potrzeba uelastycznienia obrotu gospodarczego i dopuszczenia nowych, praktycznych rozwiązań prawnych. W sytuacji braku jednolitej linii orzecznictwa SN stosunkowo często zdarzało się, że przedsiębiorcy dążyli do ustanowienia tego rodzaju prokury, składali wnioski o jej wpis do rejestru przedsiębiorców ${ }^{35}$. Decyzja o wpisie często leżała w gestii KRS.

Niezależnie od powyższego można argumentować, że zobowiązanie prokurenta do działania wspólnie z członkiem zarządu jest bezpieczniejsze dla spółki niż ustanowienie prokury łącznej, a tym bardziej samoistnej, gdzie przedstawicielami są co do zasady osoby niewchodzące $w$ skład organów ${ }^{36}$. Zarząd ma bowiem za zadanie chronić interesy przedsiębiorstwa i działać na jego rzecz, dlatego logiczne wydaje się, że taki udział w czynnościach prokurenta będzie dla spółki korzystny.

34 Ustawa z dnia 20 sierpnia 1997 r. o Krajowym Rejestrze Sądowym (Dz.U. z 1997 r. Nr 12, poz. 769).

35 Tak: A. Opalski, A.W. Wiśniewski, Glosa do uchwały SN z dnia 30 stycznia 2015 r., III CZP 34/14, „Orzecznictwo Sądów Polskich”2015, nr 10, s. 1357-1366.

${ }^{36}$ Ibidem. 
Nie mniejsze znaczenie dla przedsiębiorstwa mają kwestie finansowe. Ustanowienie prokury łącznej to dla spółki większy koszt, ponieważ należy opłacić pracę dwóch lub więcej prokurentów.

Ustawowe sformułowania „,członkiem” lub „wspólnikiem”, wskazujące na liczbę pojedynczą, nie wykluczają możliwości zastrzeżenia, że prokurent ma działać wspólnie z kilkoma osobami wymienionymi w przepisie. Oświadczenie o udzieleniu prokury powinno zatem precyzyjnie określać, czy wystarczające jest współdziałanie prokurenta $\mathrm{z}$ jednym z podmiotów wymienionych $\mathrm{w}$ art. $109^{4} \S 11$ k.c., czy też sposób wykonania prokury wymaga współdziałania trzech lub więcej osób. Odnosząc się do pojęcia „,członka zarządu”, należy zaznaczyć, że nie powinno się rozszerzać zakresu tego pojęcia na członków organu nadzoru.

Argumentem przeciw dopuszczalności prokury łącznej niewłaściwej jest możliwość wprowadzenia w błąd kontrahentów mocodawcy co do charakteru prawnego umocowania prokurenta i członka zarządu ${ }^{37}$. Mylące może być to, że raz członek zarządu będzie działał łącznie z prokurentem (tzw. reprezentacja mieszana), a w innym wypadku w ramach wykonywanej przez prokurenta reprezentacji (tzw. prokura łączna niewłaściwa). $Z$ drugiej strony informacje o sposobie reprezentacji spółki wpisywane są do rejestru przedsiębiorców, gdzie obie osoby mogą figurować w dwóch różnych rolach. Kontrahent ma prawo wglądu do wspomnianego rejestru i tym samym ma możliwość ustalenia źródła umocowania.

Ponadto odnosząc się do stanowiska SN wyrażonego w uchwale z dnia 27 kwietnia 2001 r. (III CZP 6/01), niedopuszczenie udzielenia prokury łącznej niewłaściwej uniemożliwiałoby w niektórych sytuacjach właściwe funkcjonowanie reprezentacji spółki przez utrudnienie korzystania z reprezentacji mieszanej. Jeżeli zaś ustawodawca umożliwia reprezentację mieszaną, wolno zakładać, że akceptuje on także jej optymalne wykorzystanie przez dopuszczenie udzielenia prokury $\mathrm{z}$ zastrzeżeniem działania z członkiem zarządu.

\section{Podsumowanie}

Podsumowując poczynione uwagi, należy stwierdzić, że ustawodawca słusznie zdecydował się wprowadzić instytucję prokury łącznej niewłaściwej do Kodeksu cywilnego, dostrzegając praktyczny walor takiej konstrukcji. Brak przepisu dającego expressis verbis podstawę do ustanowienia tego rodzaju prokury od lat budził kontrowersje oraz skutkował niejednolitą linią orzecznictwa Sądu Najwyższego. W swoich orzeczeniach SN przyjmował stanowisko dopuszczalności prokury łącznej niewłaściwej, chociażby poprzez stosowanie przez analogię przepisów o prokurze łącznej. Niekiedy wypowiadał się krytycznie, wskazując, że skoro nie ma w prawie polskim odpowiedniego przepisu, to jest to konstrukcja

37 P. Antoszek, Prokura łączna niewłaściwa oraz reprezentacja mieszana w spótce kapitałowej, „Przegląd Prawa Handlowego" 2010, nr 5, s. 29. 
sprzeczna z prawem, wprowadzająca kontrahentów w błąd w zestawieniu z instytucją reprezentacji mieszanej. Względy praktyczne przeciwstawiano przesłankom formalno-prawnym. Nowelizacja Kodeksu cywilnego z dnia 16 grudnia 2016 r. powinna ukrócić spory $\mathrm{w}$ doktrynie i pozwolić przedsiębiorcom na swobodne ustanawianie wybranego przez siebie rodzaju prokury, w tym prokury łącznej niewłaściwej. Możliwe będzie również ujawnienie jej w rejestrze przedsiębiorców KRS bez ryzyka kwestionowania przez sąd rejestrowy. Uregulowanie tej kwestii, budzącej spore kontrowersje w doktrynie i orzecznictwie, pozwoliło również na rozstrzygnięcie wielu dylematów związanych z czynnościami podejmowanymi przez niewłaściwie reprezentowaną spółkę. Niewątpliwie z dniem 1 stycznia 2017 r. prokura łączna niewłaściwa stała się formą reprezentacji spółki.

\section{Bibliografia}

Antoszek P., Prokura łączna niewłaściwa oraz reprezentacja mieszana w spółce kapitałowej, „Przegląd Prawa Handlowego" 2010, nr 5.

Borkowski M., Wykonywanie przez zarząd kompetencji do reprezentacji spótki z o.o., [w:] idem, Reprezentacja spótki z ograniczona odpowiedzialnościq, Warszawa 2009.

Opalski A., Wiśniewski A.W., Glosa do uchwały SN z dnia 30 stycznia 2015 r., III CZP 34/14, „Orzecznictwo Sądów Polskich" 2015, nr 10.

Pazdan M., [w:] Kodeks cywilny. Komentarz. Suplement, red. K. Pietrzykowski, Warszawa 2003.

Pyzioł W., Szumański A., Weiss I., Prawo spółek, Warszawa 2014.

Radwański Z., Prawo cywilne - część ogólna, Warszawa 2015.

Szczurowski T., Dopuszczalność prokury łącznej niewłaściwej, „Przegląd Ustawodawstwa Gospodarczego" 2017, nr 3.

Szwaja J., [w:] S. Sołtysiński, A. Szajkowski, J. Szwaja, Kodeks handlowy. Komentarz, Warszawa 1997.

Wyrwiński M., Komentarz do niektórych przepisów kodeksu cywilnego (dotyczących firmy i prokury), zmienionych ustawa z dnia 14 lutego 2003 r. o zmianie ustawy - Kodeks cywilny oraz niektórych innych ustaw, Dz.U.03.49.408, LEX/el. 2003.

Wyrwiński M., Komentarz do zmiany art. 109 (7) Kodeksu cywilnego wprowadzonej przez Dz.U. z 2003 r. Nr 49 poz. 408, LEX/el. 2003.

\section{Akty prawne}

Rozporządzenie Prezydenta Rzeczypospolitej z dnia 27 czerwca 1934 r. - Kodeks handlowy (Dz.U. z 1934 r. Nr 57, poz. 502).

Ustawa z dnia 23 kwietnia 1964 r. — Kodeks cywilny (Dz.U. z 1964 r. Nr 16, poz. 93 ze zm.).

Ustawa z dnia 20 sierpnia 1997 r. o Krajowym Rejestrze Sądowym (Dz.U. z 1997 r. Nr 12, poz. 769).

Ustawa z dnia 15 września 2000 r. Kodeks spółek handlowych (Dz.U. z 2000 r. Nr 94, poz. 1037 ze zm.).

Ustawa z dnia 16 grudnia 2016 r. o zmianie niektórych ustaw w celu poprawy otoczenia prawnego przedsiębiorców (Dz.U. z 2016 r. poz. 2255).

\section{Orzeczenia}

Uchwała SN z dnia 18 lutego 1938 r., CI 170/37, OSNC 1938/12/561.

Uchwała SN z dnia 27 kwietnia 2001 r., III CZP 6/01, OSNC 2001/10/148. 
Uchwała SN z dnia 23 sierpnia 2006 r., III CZP 68/06, OSNC 2007/6/82.

Uchwała SN z dnia 30 stycznia 2015 r., III CZP 34/14, OSNC 2015/7-8/80.

Wniosek Pierwszego Prezesa Sądu Najwyższego z dnia 11 kwietnia 2014 r., BSA I-4110-5/14.

\section{Źródło internetowe}

http://ksiegowosc.infor.pl/obrot-gospodarczy/spolki/734421,Prokura-udzielenie-wykonywanie-wypowiedzenie.html.

\section{Admissibility and the legal nature of inappropriate joint procuration in the light of the amendment of the Civil Code of 16 December 2016}

\section{Summary}

In conclusion, the legislator has rightly decided to introduce the institution of an inappropriate joint procuration to the civil code, recognizing the practical value of such a construction. The lack of the basis for establishing such a legal construction has been controversial for years and has resulted in many different Supreme Court position statements. In its rulings, the Supreme Court agreed on admissibility of the inappropriate joint procuration, even by applying it by analogy. Sometimes the Court was critical pointing out that, since there is no expressis verbis legal basis in Polish law, this construction is against the law. Practical considerations were opposed to formal and legal requirements. The amendment of the Civil Code of 16 December 2016 should curtail disputes in doctrine and allow businesses to freely establish the selected kind of procuration. Undoubtedly from the 1st of January 2017 the inappropriate joint procuration has become an admissible form of company representation. 